\title{
INDIVIDUAL DIFFERENCES IN STUDENTS IN THE ELEMENTARY SCHOOL ENVIRONMENT
}

\author{
Hasanah Dwi Wahyuni $^{1}$, Shinta Anjani Nura ${ }^{2}$, Ina Magdalena ${ }^{3}$ \\ ${ }^{1,2,3}$ Pendidikan Guru Sekolah Dasar, Universitas Muhammadiyah Tangerang, Indonesia
}

\section{Article Info}

Article history:

Received: 03-02-2021

Revised: 08-08-2021

Published: 30-09-2021

\section{Keywords:}

Individual

Education

Individual Differences

Learning Styles

Learning

\begin{abstract}
Every human being was created by the Creator with all the uniqueness and characteristics of each. This arises as individual differences (individual differences). Individual differences are differences in abilities and characteristics (cognitive, personality, physical skills, and so on) between students at a certain age level and in each particular group. Through educational practices and activities, we can accommodate the individual differences of students. Likewise, the learning styles between each other are also different. There are visual, auditory, and kinesthetic learning styles. It is important to recognize the learning styles of students so that teachers can vary their teaching styles, learning methods that are suitable to be applied in the learning process. As a technique, we must be able to choose various ways that can accommodate these differences personally and optimize the improvement and interpersonal skills of each student in the long term, especially when viewed from the learning style so that it can be carried out optimally. Individual differences that need to be considered in the implementation of classroom teaching are factors related to the readiness of children to receive teaching because these differences will determine the education system as a whole. Factors that influence individual differences are: self-concept (self-concept), locus of control, student anxiety, learning motivation.
\end{abstract}

This is an open access article under the CC BY-SA license.

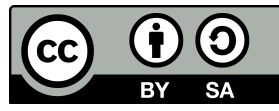

\section{Corresponding Author:}

Hasanah Dwi Wahyuni,

Pendidikan Guru Sekolah Dasar, Universitas Muhammadiyah Tangerang,

Jl. Perintis Kemerdekaan I/33 Babakan, Tangerang, Indonesia

Email: hasanahdwi02@gmail.com

\section{INTRODUCTION}

In fact, each individual has a different tendency. Overall, these differences are more quantitative than qualitative. Everyone, whether he is a child or an adult, and whether he is in a group or alone, is called an individual. Individual shows a person's position as an individual or individual. Characteristics and characteristics of one person is different from another. These differences are called individual differences or individual differences. Each individual is created with all its uniqueness and with their own characteristics. Hereditary or congenital factors as well as environmental factors are factors that influence personal/individual differences. These two factors affect the development and growth of students. As for the various learning styles, namely visual learning styles, namely the ability to learn by seeing, auditory learning styles, namely having better abilities in hearing, kinesthetic learning styles, learning by involving movement styles.

Teachers should not equate all their students. To get optimal learning, a teacher must know what students need and try to help meet their learning needs (Zagoto, Yarni, \& Dakhi, 2019). This research is expected to provide benefits for various parties, including benefits for teachers, for students, for institutions and 
for researchers. The benefit of this research for teachers is to provide insight into knowledge about innovative learning models, as a consideration when teaching other learning materials applying the make a match learning model. The benefits of this research for students are being able to foster student interest in learning when participating in learning in particular, making it easier for students to capture learning material. The benefits of this research for institutions are as input and consideration to overcome problems when improving student learning outcomes, can improve and improve the quality of education in schools. The benefit of research for researchers is to increase knowledge, especially about interesting and varied learning models, for researchers' capital in understanding varied learning models in order to improve student learning outcomes so that later they can be implemented when they become teachers.

\section{RESEARCH METHOD}

The research method that the author uses is descriptive research assisted by a qualitative approach, the analysis is carried out by looking at the percentage distribution of each measurement aspect. The subject of this research involves many parties to strengthen the results that the author examines, it is felt that it will be more accurate if the author gets a lot of votes from several respondents or several subjects. The characteristics of each student in a school or an institution will certainly vary from individual to individual, requiring a strong approach and theory from several sources as well as actively asking the various parties involved. The research was conducted on Tuesday, January 19, 2021 and also the continuity of this research was carried out by distributing or sending online forms to respondents. Because the author uses qualitative research, the instrument that the author uses is by using the main tool or instrument for data collection that requires humans or the researcher himself through observing, asking, listening, asking and taking research data. Researchers must obtain valid data so that not just any interviewee is interviewed.

From the theoretical sources that the authors found, the analysis in this study uses qualitative because the qualitative data analysis method is a method of processing data in depth with data from observations, interviews, and literature. The advantage of this method is the depth of the analysis results. It also uses a Classroom Action Research (CAR) design. CAR comes from problems found by teachers during classroom learning activities. According to Arikunto (Arikunto, 2012), CAR is a research carried out by teachers in their class which has the intention to improve and improve the quality of learning in the classroom. With this research, teachers can detect the weaknesses experienced by students and take action to deal with student problems. This research was conducted with the hope that teachers can reflect on themselves about the educational services that have been provided to students so that they can improve the quality of learning in school institutions. Classroom Action Research has several characteristics, namely:

1. In terms of problems, the characteristics of CAR are problems that are raised from problems of practice and the daily learning process in the classroom that are really felt directly by the teacher.

2. Classroom Action Research always departs from the teacher's critical awareness of the problems that occur when learning practices take place, and the teacher realizes the importance of finding solutions to problems through action.

3. There is a plan of certain actions (actions) to improve the practice and learning process in the classroom.

4. There is a collaborative effort between the teacher and other colleagues (teachers or researchers) in order to help observe and formulate the basic problems that need to be addressed.

Classroom action research (CAR) is a controlled investigative process to find and solve learning problems in the classroom, which is carried out cyclically, with the aim of improving the quality of learning processes and outcomes in certain classes. The main characteristics of CAR are:

1. The problem comes from the setting/class where the research is conducted.

2. The problem solving process is carried out in a cycle.

3. The goal is to solve learning problems in the classroom or improve the quality of learning in the classroom.

This CAR will use research in a cyclical manner. Researchers designed 2 cycles. If the results of the research in cycles I and II have not reached maximum results, a research will be held in the next cycle. This research will apply the CAR procedure developed by Kemmis and Mc Taggart. The stages in this research include 3 stages, namely Planning, Treatment and Observation, and Reflection. 


\section{RESULT AND DISCUSSION}

Each individual has different characteristics, as well as the various learning styles of students. Individual differences can be caused by two factors, namely differences that are influenced by heredity or differences that are influenced by the environment. Therefore, as an educator is expected to be able to recognize and understand the differences in their students.

Individual differences are important to understand because different individual characteristics often cause problems. From the problems that arise, educators can find out various kinds of individual differences, including language differences, differences in achievement levels, differences in background and others. These differences need to be handled in the context of learning efforts. Therefore, as a candidate for an educator should be able to understand every characteristic and nature of each individual or student.

Learning style (Learning style) is a technique that we prefer in doing activities of thinking, processing and understanding/understanding an information (Gunawan, Harjono, \& Imran, 2016). Learning style can be defined as the way a person responds to an information/lesson, organizes, and manages that information for problem solving and applying it in his life. Learning style is a technique / way that a person has to explore his abilities (Masril, Jalinus, Jama, \& Dakhi, 2020; Zagoto et al., 2019). According to DePorter \& Hernacki (2013) learning styles are categorized into three.

\subsection{Visual Learning Style}

According to Faiza et al. (Faiza \& Dara, 2017), the visual learning style (visual learner) is more focused on vision. Visual learning style looks at visual views, both generated and remembered. In this type of learning style, portraits, colors, and spatial relationships, as well as drawings/sketches are more prominent. Students with visual types have characteristics, namely: neat and directed, speak appropriately, designers and managers who are steady, observant, thorough and detailed, good pronouns and can see the actual words in the mind, remembering what is seen rather than what is seen. listened to, diligent reader, often answers questions with short answers, yes or no likes to read rather than be read prefers to do presentations/shows rather than just lecturing; and prefer art. Children with visual types must pay attention to the teacher's expressions when teaching in order to understand the lesson material. They are very interested in sitting in the front so that they can see clearly. Thinking by applying portraits/figures in their brains and understanding things faster through visual animations, such as picture books, or videos.

Approaches to assist the learning process of students with visual learning styles:

1. Take advantage of visual materials/objects, for example, maps and pictures/diagrams.

2. Take advantage of color to make it easier to understand important things/points.

3. Encourage children to read picture books or animations.

4. Digital media such as: computer/video.

5. Invite children to present their ideas in sketches.

\subsection{Auditory Learning Style}

Auditory learning styles (auditory learners) focus on the sense of hearing in remembering something. The hallmark of this type of learning style really uses the sense of hearing as an essential tool to absorb information/knowledge. That is, students must listen, then can understand / remember the information obtained. This learning style manages all kinds of sounds and words. Tone, music, rhythm, and internal dialogue and voice are more accentuated for this type of learning style. Someone with an auditory type has characteristics, namely: easily distracted by noise, pronounces writing or reads aloud while moving their lips while reading, reads aloud and can repeat and imitate voice colors, and tone has difficulty in writing but has competence in conveying/presenting stories, speakers who are smart/fluent, like music, like to give opinions, and describe things in detail. They have difficulty with things related to visualization, for example grouping an element to fit one another.

Approaches/strategies to assist the learning process of auditory children:

1. Always involve children in discussion activities.

2. Give motivation to read the lesson material aloud.

3. Vary the use of music when teaching children.

4. Discuss ideas orally.

5. Invite the child to record the lesson material on a cassette. 


\subsection{Kinesthetic Learning Style}

Kinesthetic learning styles (kinesthetic learners) require personal to touch/touch something that conveys certain information/data for students to remember. Kinesthetic children learn through moving, doing, or touching. Children with this type find it difficult to sit still/silent because their desire to explore and engage in activities is so strong. Children with this learning style learn through movement and touch. The characteristics of kinesthetic children are: touching/holding/touching to get people's attention, speaking slowly, responding to physical attention, standing close to the other person, always physically oriented and moving a lot; have early growth/development of large muscles; learn by manipulating and practicing; memorize/remember by walking/seeing; pointing to the reading while reading; use a lot of body cues; and cannot sit still for long. Strategies/approaches for teaching kinesthetic children:

1. Does not require children to study for hours.

2. Invite children to learn by exploring/exploring their environment.

3. Mark the important points of a passage in bright colors.

4. Give children permission to study while listening to music.

According to a psychological review, every child is different from the others. "There are no two people in this world who are truly the same in all respects, even if they are twins" (Nurdin, 2005). No wonder someone said that "twins are similar but not the same". This means that in certain cases twins have similarities and differences (Djamarah, 2011; Magdalena, Septina, Az-zahra, \& Pratiwi, 2020). Individuals here have an understanding that is a unity, each of which has its own characteristics, and therefore no two individuals are the same, each other is different (Hamalik, 2004). Individual differences can be seen from two aspects, namely: horizontal and vertical. From a horizontal perspective, each individual is different from other individuals in mental aspects, such as: level of intelligence, ability, interest, memory, emotion, will and so on. In terms of vertical, no two individuals are the same in physical aspects such as shape, size, strength, and endurance. Each of these differences has advantages and disadvantages. There are two factors that cause individual differences, namely:

1. Heredity (Nature)

Hereditary factors are biological factors that are passed down through genetic mechanisms from generation to generation. Hereditary factors are determined by the chromosomes brought from the mother through the egg/ovum and from the father through the spermatozoa. Differences in genes in each individual is the reason why there are physical, trait, psychological and behavioral differences with other people and even with siblings. Each gene contains instructions for the production of proteins that will shape the body, physical strength, intelligence, traits, and other behaviors as inherited traits from their parents. However, this heredity does not necessarily become the most decisive factor in the emergence of individual differences. The other factors that can influence individual differences are environmental factors. This is because each individual will always live and develop in a certain environment and will never be in the exact same environment.

2. Environmental Factors (Nurture)

Individual development is not only determined by heredity, but is also determined by the influence of the surrounding environment. For example, a child born in a rich family will behave differently from a child born in a poor family. According to Wasty Soemanto environmental factors are everything that is outside an individual, both physiological, psychological, and sociocultural that can affect an individual's personality. In other words, individuals will accept the influence of the environment, set an example for the environment, imitate or learn about various things from the environment. The environment is divided into three parts, including:

(a) Family Environment

The family has a very important role in developing the child's personality. The family environment is the starting place to find out children's talents and make it a place for talent training that exists in children. Parents guide their children to reach their talents.

(b) School Environment

The school environment can be used for children in the teaching and learning process and can influence children's interests and talents to be developed intensively and teachers are responsible for the talent development process in schools.

(c) Community Environment

The community environment is a teenager's social environment, because in general children social- 
ize with their peers. This environment has an important role in the development of his personality. The main factors that determine interpersonal attractiveness between adolescents are similarities in interests, values, opinions, and personality traits. While at school include: educational expectations or aspirations, grades (learning achievement), assignments and so on. One of the differences that stand out in relation to the world of education is ability (intelligence). This is because intelligence is an element that influences the success of students' learning.

Environmental factors refer to everything that happens outside the individual, these factors include:

(a) The socioeconomic status of parents is the level of parental education that influences individual development from childhood to adulthood. For example, the higher the level of education, the higher the perspective in educating and the aspirations for education for children. Although it is not absolute, the level of parental education affects parents' attitudes towards children's education. Likewise, the work and stage of parents are different and also differences in economic status will affect individual differences, one of which is the difference in nutritional patterns applied in the family. Nutrition is an important aspect that affects the development of children's intelligence and the best nutrition is a need that must be met in children for physical and intellectual growth and development.

(b) Culture is thought, reason, the work of humans, or can be defined as customs. Culture and culture as a series of patterned human actions and activities can be seen in 3 forms. The first form is the ideal form of culture in the form of ideas, ideas, values, norms, rules and so on. The second form is the culture of an activity and patterned action of humans and society. The third form is culture as objects made by humans.

(c) Birth order several studies show that individual behavioral education is influenced by birth order. According to Alfred Adler's theory, birth order affects the way a person handles a problem and factors such as decision making, communication, and dealing with other people.

So, it can be understood that intelligence is the ability to understand and adapt to new situations quickly and effectively, the ability to use abstract concepts effectively, and the ability to understand relationships and learn them appropriately (Marbun, 2018). In order to determine the level of intelligence of a person, an instrument known as the "Intelligence Test" was developed and the description of the test results became known as the Intelligence Quotient, abbreviated as IQ. Based on the results of intelligence tests, it is known the criteria for classifying intelligence (Magdalena, Pasyah, \& Hasanah, 2020; Mulyasa, 2005).

According to Lindgren's opinion in Nini Subini (2012) states that the types of individual differences that exist in individuals can be distinguished as follows:

1. Cognitive Difference. Is the ability related to the mastery of science and technology. Everyone has a perception of the results of observation or absorption of an object, which means he controls everything he knows.

2. Differences in Language Proficiency. It is one of the most important individual abilities in life. The ability of each individual in the language is different. Language ability is a person's ability to express his thoughts in the form of meaningful, logical, and systematic expressions of words and sentences. Language ability is greatly influenced by intelligence factors and environmental factors as well as physical factors.

3. Differences in Motor Skills. Is the ability to coordinate motor nerve movements carried out by the central nervous system to carry out activities. Factors that affect motor skills are physical growth maturity and level of thinking ability.

4. Background Difference. It is a person's achievement that can be hampered or accelerated due to differences in one's background and experience. This is apart from the potential of each person to learn and master various information.

5. Talent Difference. Is a special ability that is brought from birth, talent can develop well if someone gets the right stimulation. Meanwhile, if the environment does not provide opportunities for one's talents to develop, then these talents will not be honed and developed properly.

6. Differences in Learning Readiness. It is the difference in background which is included in the socioeconomic, socio-cultural differences, which are very important for the development of children. As a result, children of the same age are not always at the same level of preparation to receive wider outside influences.

7. Behavioral Differences. Some people have more positive attitudes toward a particular topic, subject, and 
profession than others. This positive behavior can be produced through education given, of course, since childhood.

8. Value Difference. It is something that is considered important by the individual. Some people think that material things are more important than moral values, others think otherwise.

\section{CONCLUSION}

Sources of individual differences in education and learning explain the differences related to student differences in thinking, feeling, and acting. The factors that influence, causing the emergence of characteristics of individual differences are heredity factors and environmental factors which include the natural environment and the social environment. In addition to individual differences, there are also various individual differences which include abilities, language skills, motor skills, backgrounds, talents, learning readiness, behavior and values. The basic concept of individual differences is that each individual generally has similarities and differences. Individual differences related to the discussion in psychology is a personality that discusses the psychological differences and similarities between individuals in their social environment.

From the results of the interviews we conducted, it can be concluded that students must have different characters, but that is not a difficult thing for the teachers to deal with, the teachers only need to process the rules. And for teachers there is no difference in learning methods, it's just that teachers can provide understanding, motivation in learning and guide students who do have problems in learning. Because basically all students are smart but smart in their respective potentials.

\section{REFERENCES}

Arikunto, S. (2012). Prosedur Penelitian : Suatu Pendekatan Praktik (Edisi Revisi).

DePorter, B., \& Hernacki, M. (2013). Quantum Learning: Membiasakan Belajar Nyaman dan Menyenangkan. Bandung: Kaifa Learning.

Djamarah, S. B. (2011). Psikologi Belajar. Jakarta: PT. Rineka Cipta.

Faiza, R. U., \& Dara, Y. P. (2017). PSIKOLOGI PENDIDIKAN. Surabaya: UB Media.

Gunawan, G., Harjono, A., \& Imran, I. (2016). PENGARUH MULTIMEDIA INTERAKTIF DAN GAYA BELAJAR TERHADAP PENGUASAAN KONSEP KALOR SISWA. Jurnal Pendidikan Fisika Indonesia, 12(2), 118-125. doi:10.15294/jpfi.v12i2.5018

Hamalik, O. (2004). Proses Belajar Mengajar. Jakarta: Bumi Aksara.

Magdalena, I., Pasyah, F. A., \& Hasanah, N. (2020). Implikasi perbedaan individu peserta didik sekolah dasar. PENSA : Jurnal Pendidikan dan Ilmu Sosial, 2(3), 283-297.

Magdalena, I., Septina, Y., Az-zahra, R., \& Pratiwi, A. D. (2020). Cara mengembangkan bakat peserta didik. Bintang: Jurnal Pendidikan dan Sains, 2(2), 278-287.

Marbun, S. M. (2018). PSIKOLOGI PENDIDIKAN. Jakarta: Uwais Inspirasi Indonesia.

Masril, M., Jalinus, N., Jama, J., \& Dakhi, O. (2020). IMPLEMENTASI PEMBELAJARAN BERBASIS MASALAH PADA KURIKULUM 2013 DI SMK NEGERI 2 PADANG. Konstruk, 12(1), 12-25.

Mulyasa, E. (2005). Menjadi Guru Profesional. Bandung: PT Remaja Rosdakarya.

Nurdin, S. (2005). Model Pembelajaran yang Memperhatikan Keragaman Individu Siswa dalam Kurikulum Berbasis Kompetensi. Ciputat: Quantum Teaching.

Subini, N. (2012). Psikologi Pembelajaran. Yogyakarta: Mentari Pustaka.

Zagoto, M. M., Yarni, N., \& Dakhi, O. (2019). PERBEDAAN INDIVIDU DARI GAYA BELAJARNYA SERTA IMPLIKASINYA DALAM PEMBELAJARAN. Jurnal Review Pendidikan dan Pengajaran, 2(2), 259-265. doi:10.31004/jrpp.v2i2.481 